\title{
DOMESTIC VIOLENCE IN THE CONTEXT OF THE EDUCATION OF SENIORS
}

\author{
KATEŘINA ŠMEJKALOVÁ \\ Masaryk University, Faculty of Education,

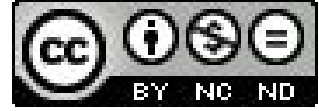 \\ Department of Physics, Chemistry and Vocational education, \\ Pořičí 7, 60300 Brno, Czech Republic. \\ E-mail address: 5699@mail.muni.cz
}

\begin{abstract}
The article discusses domestic violence as dangerous, unlawful and violent conduct, which currently threatens the generation of seniors. The author stresses the need for primary prevention of domestic violence in the context of the education of seniors at the University of the Third Age. In the text the author presents the content focus of preventative lectures to the target group of seniors. In connection with the content of primary prevention is highlighted to the opportunity to help the victims of domestic violence through the association for assistance to victims of crime "Bílý kruh bezpeči“. On the basis of the exploratory investigation, the views of seniors on the issue of the domestic violence are presented in the text.

Key words: education of seniors, victim of domestic violence, prevention of domestic violence, protection of victims, violent person
\end{abstract}

\section{INTRODUCTION}

Domestic violence goes across the socio-demographic composition of society. In the overall picture and in each case they apply different groups of causes of this violence (Čírtková, 2014, p. 67). Domestic violence is often described as the most widespread form of violent behaviour in society (Buskotte, 2008 , p. 17). Surprising is the fact that the probability of being attacked, injured or killed in a safe home for family members is three times greater than the likelihood of attack on the street, and that every eight Czech woman are beaten by partners. Domestic violence is latent, the least controlled, and from the perspective of frequency and severity the most underestimated of the social forms of violent behaviour (Ševčík, \& Špatenková, 2011, p. 22).

As an introduction it is important to mention one of the definitions of domestic violence, which was established by the Council of Europe Convention on the prevention and combating of violence against women and domestic violence in 2011. Literally here it was noted that domestic violence means all 
acts of physical, sexual, psychological and economic violence that occurs in the family or in the home, or between former , or existing spouses or partners, regardless of whether the perpetrator shares or has shared a common household with the victim (http:/ / xoe.int/t/dghl/standardsetting/convention-violence/convention/Convention $\% 20210 \% 20$ Czech.pdf).

Domestic violence affects all categories of people, regardless of their education, age or ability as applicable to to the labour market. There are certain specifics in the behavior of the victim. The victim at the time of the call for help is under a strong psychological pressure, and generally lacks self-confidence. The breakdown of victims of domestic violence can be divided into children, women, men and the elderly (Ševčík, \& Špatenková, 2011, p. 126).

Domestic violence against the elderly - the victim, in this case a senior, may not know at the beginning, that the members of the family, with which it shares the household, have a propensity for violence (Šmejkalová, 2011, p. 38). Only in stress situations (the emergence of the depending on the help of the others, the loss of certain skills - particularly the ability to participate in the running of the household, the incipient mental problems of the victim), some family members may begin to behave aggressively (Voňková, \& Spoustová, 2008, p. 70). At the time of the tyranny the victim of this is so surprised, the majority iare not able to adequately respond. Alarming for this group of victims is the fact, that the situation in large measure also applies to care in institutional facilities (Fischer, \& Škoda, 2014; Buriánek, 2006).

Especially in the area of the primary prevention of risk behaviour known as domestic violence, is at the time very desirable (Vágnerová, 2014, p. 354). The aim of primary prevention is under the national action plan for prevention of the domestic violence in the context of the Czech Republic, in particular, the involvement of the public. In terms of public opinion, it is necessary take advantage of every available way to eliminate entrenched cultural and social stereotypes that make violent people legitimate. (ttp://www.koordona.cz/ domaci-nasili/legislativa/60-narodni-akcni-plan-prevence-domaciho-nasilina-leta-2010-2014.html). It is therefore necessary to make use of their elimination by every lawful and constitutionally conformal procedure, involving both legal resources (change the laws), additional methods, such as the solution of the problems. realization of information campaigns. The national action plan for the prevention of domestic violence in this area calculated with the use of other educationlly effective tools, such as awareness-raising activities, the Conference or the extension of teaching at schools (http://www.dejmezenamsanci.cz/res/data/010/004403.pdf?seek=4).

In the above mentioned context at the University of The third Age, which is part of the Masaryk University, in the year 2015 a specialised lecture specialised lecture took place on the theme of the domestic violence in the context of the new legislation. The time allotted for the lecture was two hours, it means 45 min $\times 2$ (http://u3v.muni.cz/o-nas/). The aim of the lecture was to inform seniors about issues, that no doubt could be touched upon. The lecture drew 
attention to the basic concepts, the definition of domestic violence, expressions of the analysis of risk behavior and the specifics of the seniors in the role of victim. The lecture then resulted in the specific procedure of the victim or a witness of defense against domestic violence, i.e.. The possibility of filing a criminal notification to the police of the Czech Republic, for help on the other helping agencies. For example The „Bílý kruh bezpeči“ association, that since 1996 is a full member of the transnational organization of Victim Support Europe (previously The European Forum for Victim Services), that actively cooperates in the development of projects, standards, researches, reviews, implementation of the documentation for the framework decisions of the Council of the European Union in the field of the treatment of victims of crime in the EU (Čírtková, 2014; http://www.bkb.cz/).

The "Bílý kruh bezpečí association in nine of the counselling regions in the Czech Republic (Prague, Plzeň, Liberec, České Budějovice, Pardubice, Jihlava, Olomouc, Ostrava, Brno, Czech Republic) provides a professional, free, impartial and discreet assistance to victims of crime, witnesses and survivors of the victims including the moral and discrete support (http://www.bkb.cz/). Direct assistance is based on the personal contact with a pair of consultants, a lawyer and expert on the psychological assistance. This service is provided free of charge in the role of volunteers (http://www.bkb.cz/).

The content of the lectures was mainly elected because of the assumption that the issue of the domestic violence for persons over 65 years old are still a taboo. Part of the lecture was a reconnaissance probe, whose objective was to verify this claim.

\section{OBJECTIVE}

The main objective of the exploration of the probe's work was to find out what kind of awareness seniors have about the analysis of risk behavior, where they consider the problem as socially significant, where they see the causes, and whether they know where to turn for help if necessary. The exploration of the investigation took place in the framework of the lecture at the University of the Third Age, Masaryk University.

The views of respondents on the issues of the elderly - domestic violence.

\section{THE METHODOLOGY}

The search medium consisted of 30 respondents, assisted on 20th March 2015 at a lecture on the theme of domestic violence, focusing on its prevention. The respondents were students of the University of the Third Age, Masaryk University. A participant in the program of the University of the Third Age can become a person who has reached the age required for the granting of old-age 
pension and has full secondary education with a leaving exam (http://u3v. muni.cz/o-nas/). The students of the University of the Third Age are students under Act No. 111/1998 Coll. on universities. Teaching in the context of long-term rates takes the form of lectures, tutorials, seminars or excursions. Each lecture lasts 2 hours and they are held once every two weeks from September to May in the academic year (http://u3v.muni.cz/o-nas/). In the course of the training it is not necessary to undergo any form of participant evaluation (http://u3v.muni.cz/o-nas/).

The Age of respondents ranged from 63 years to 85 years. The average age was 71 years of age. Of the 30 respondents were 4 men and 26 women. For transfer and data evaluation questionnaires into electronic form has been used Microsoft Excel 2010. Return of the questionnaires was $100 \%$. The evaluation was carried out on 30 respondents.

\section{THE EVALUATION OF THE QUSTIONNAIRE SURVEY}

The questionnaire survey was carried out anonymously, when respondents filled out a questionnaire (Appendix 1) in printed form. The selection of respondents was more or less random, the respondents have in common only the fact they were schooled at the University of the Third Age of the Masaryk University. From which it is clear that they are of pensionable age and have full secondary education with leaving exam. You can also have reason to believe that the respondents came from the city of Brno, and from the outskirts the city of Brno.

The graphic quantitative assessment of individual questions from the questionnaire confirms the topicality of domestic violence as a problem of contemporary society, even by the elderly. $94 \%$ of respondents believe that at present the issue of the domestic violence is really a social problem (Graph No. 1). $70 \%$ of respondents believe that the existing legislation inadequately protects the victim (Graph No. 2). It can be assumed that these $70 \%$ of respondents believe that the existing legislation in the Czech Republic acts preventatively against the occurrence of the domestic violence (Graph No.3). As shown in Graph No. 3, from $70 \%$ of the respondents, $7 \%$ of the situation could be assessed.

The reaction of respondents was very interesting as to the potentiality of the threat (Graph No. 4). Respondents could select more than one answer, which some did. $63 \%$ of respondents see their social group as a vulnerable of the elderly. If we want to search the cause as to why they have designated their own social group as the threatened, we would have to examine the issue more deeply. The answer may be given, for example in the current media output on individual causes, non intentional ignorance of the nature of the analysis to the problem or a simple link - the lecture is on a topic that dosen't concern me. However, it may be a condition where the respondents really feel threatened 
themselves by the domestic violence, or they have a concern about their peers such as from the place of residence.

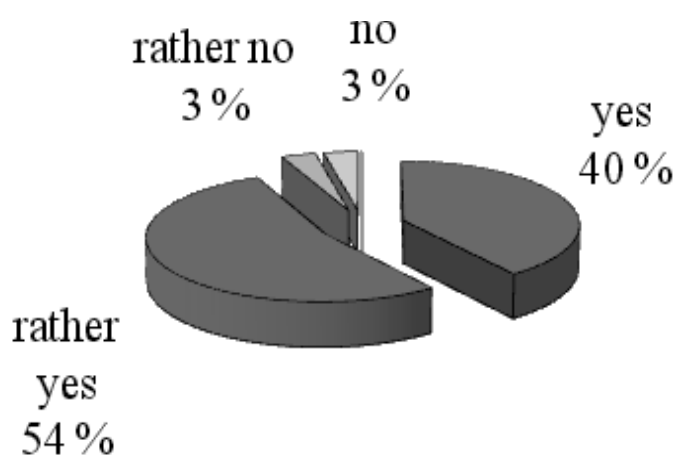

Graph No. 1. Do you think the issue of domestic violence is really a social problem?

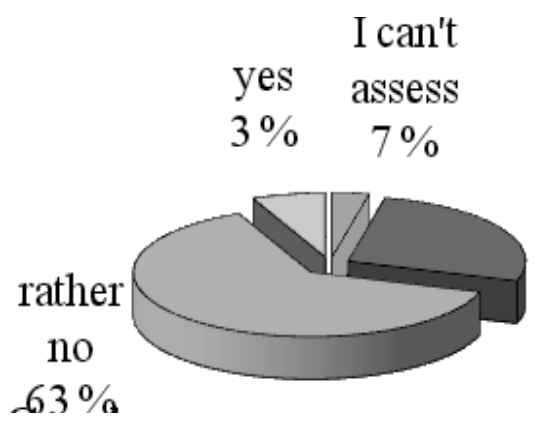

Graph No. 3. Do you think the current law acts preventatively against the occurrence of a domestic violence?

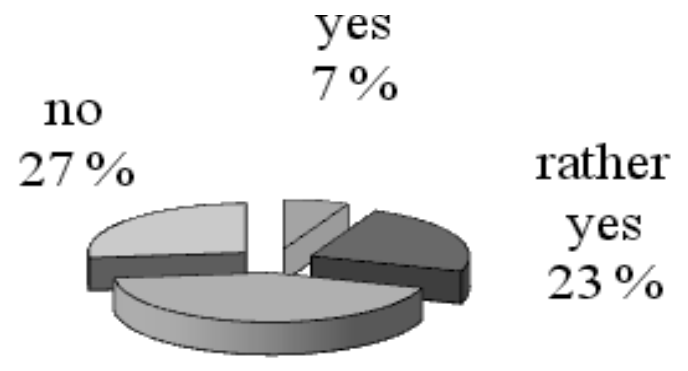

rather no

$43 \%$

Graph No. 2. Does the legislation protect the victims of domestic violence sufficiently?

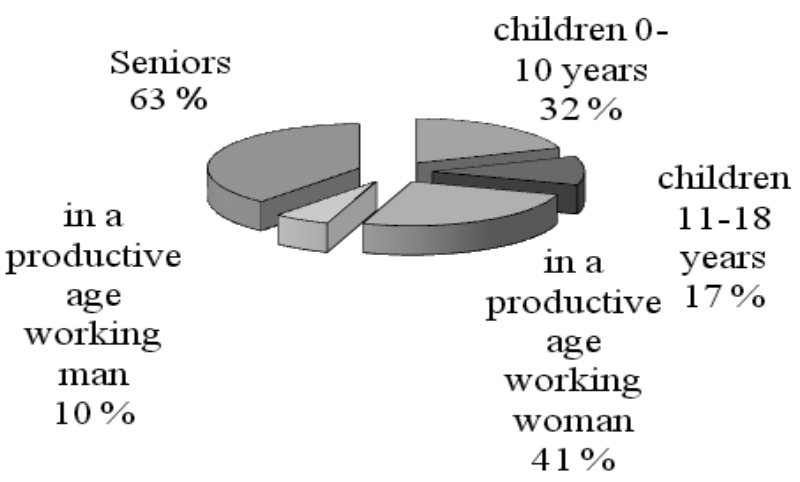

Graph No. 4. Who are the most frequent victims through the social profile of the domestic violence according to your opinions?

A question that explores a lay opinion on the communication of the respondent to the Police of the Czech Republic, is not targeted to causes of the domestic violence. The respondents indicated that their experience may not apply to the time period, or to a specific action. The question was deliberately very general. The result of the survey showed that each of the respondents has met with an officer of Police of the Czech Republic. 57 \% of the respondents attached themselves to the response, that their communication with a officer of Police of the Czech Republic was not good. (Graph No. 5).

$54 \%$ of respondents believe they can prevent domestic violence. (Graph No. 6). The question, how is it possible to prevent the problem, was answered by 17 respondents. In their free answers respondents mentioned for example the medialisation of the problem, the education aimed at seniors in the area of law and psychology, functional educational environment in the family, in particular education for responsibility, justice and respect, early and adequately 


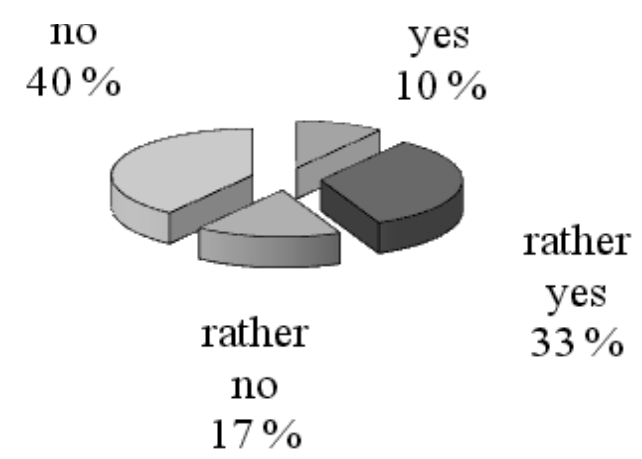

Graph No. 5. Do you have a good experience about the communication with a policemen of the Police of the Czech Republic?
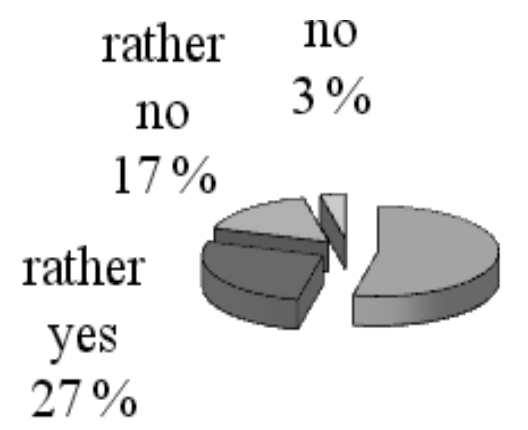

yes
$53 \%$

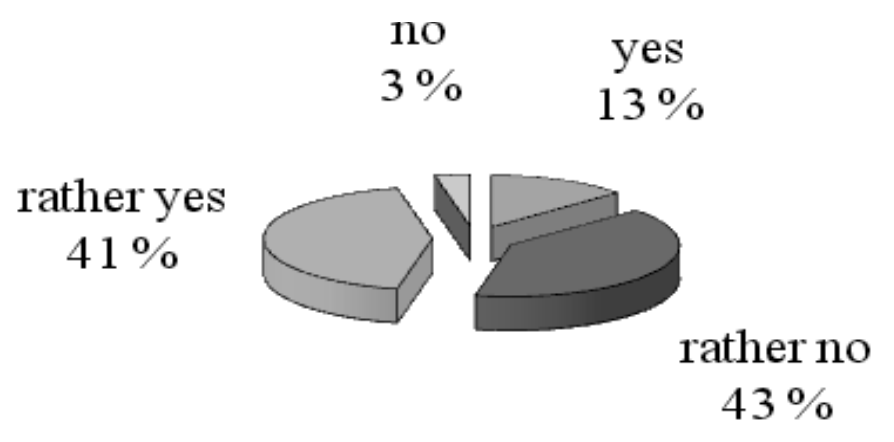

Graph No. 6. Do you think we can prevent domestic violence?

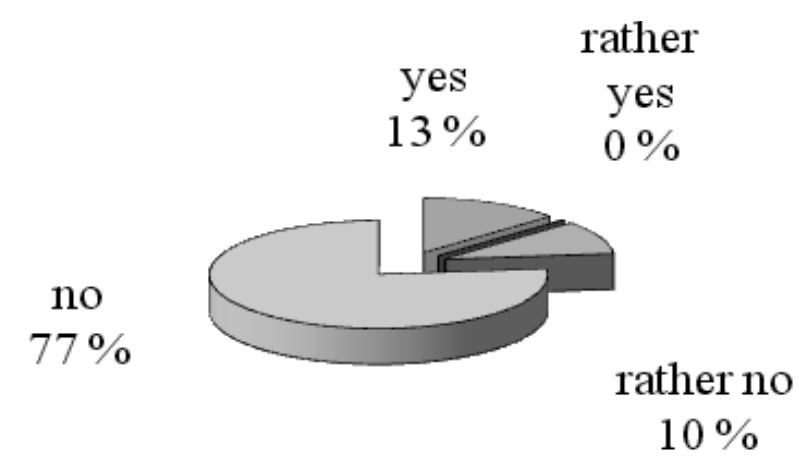

Graph No. 8. Have you ever participated at the lectures about the topic of domestic violence in the past?

respond to starting violence, etc. 25 of the respondents took advantage of the opportunity to freely express what they see as the biggest problem in the detection of domestic violence. Respondents independently agreed that the problem with the solution is in fear of the victim of the aggressor and stood in front of the other people. The victim is afraid and ashamed.

$80 \%$ of the respondents subsequently stated that they know which subject to turn to if necessary (Graph No. 7). 19 of the respondents in the following free answers stated that they would turn for aid to the Police of the Czech Republic. 6 of the respondents said that they give credit to the Police of the Czech Republic. The remaining 12 of the respondents commented the answer "no more" One respondent stated he supposed that the Police of the Czech Republic can hit quickly. The answers correspond with the result of the answer given in Graph No. 5. Another variant of the answers was the possibility to turn to the „Bílý kruh bezpečí" association, on the doctor, psychologist, or a friend.

It can be presumed that the obtained answers really match the result of the last questions of the questionnaire (Appendix 1), where 26 of the respondents. $87 \%$ have mentioned, that they had not participated or personally attended with a targeting awareness of the lecture on the theme of the domestic violence in the past. (Graph No. 8). 


\section{DISCUSSION}

Criminal variables, risk factors are related to the victims and violent persons. These variables should act as a warning signal for doctors and other persons who may come into contact with the victim (Čírtková, 2014, p. 69). To this finding have independently come 6 respondents. $20 \%$ and by their free answers following-up on Graph No. 6. For example respondents indicated that domestic violence can be prevented: ",... quality relationships in the family“ ${ }^{\prime}, \ldots$ "it depends on the nature of the abuser, usually the victim alone can't handle", ... „, in the right direction of young people and children in the family."

As factors increasing the exposure of seniors to maltreatment, is often quoted in the literature: the overall poor health ,disorders, cognitive and communication functions, loss of self-sufficiency, social isolation, living with a violent person and dependency on it (Buriánek, 2006, p. 83). On the other hand, no small role is played nowadays to material, and housing dependency of the victim to the violent person, overloaded and existential problems of families and a decrease in the willingness and capabilities of family members to provide quality care, etc. Not coincidentally, the deterioration of the family relationship is involved in unemployment, alcoholism, drug addiction, previous aggressive or antisocial conduct violent persons (Buskotte, 2008, p. 29; Čírtková, 2014, p. 94).

If we think about contemporary society so, what it really is, especially known to the high pace of life with all the negative effects on human beings, it is not easy for any generation to live (Vágnerová, 2014, p. 351). It is necessary to especially note that the elder person becomes to be uneasily to any amendment of affecting himself, with the age of the growing risk of various illnesses (dementia, personality disorders and behaviour, mood disorder, anxiety disorder phobia), the burden of the departure of the close member of the family, death in the family, the disintegration of families caused by divorce. It can be said that everything depends on the relationships between family members (Vágnerová, 2014, p. 317; Čírtková, 2014, p. 68). The most common causes of conflicts are just disagreements and disruption of these relationships (Vágnerová, 2014, p. 352).

What should be the primary prevention? We can only agree that it depends on the level of the family environment. The effort should primarily be to attach the functionality of the family environment in the process. In this field a single educational process for the family, the school might help, a non-governmental and voluntary organisation working against violent behavior, peer groups, but also the personality of each individual. Simply said, society as a whole (Fischer, \& Škoda, 2014). The part of primary prevention targeted to seniors in the area of crime and violence, should be given greater attention. The warning signal is that within the exploratory probe $87 \%$ of respondents have mentioned they so far had not met with any targeted training on the topic of domestic violence (Graph No. 8). So, we can rightfully assume, because of the examined group of 
respondents, they have information and different natures of interest. The trend of primary prevention, not only due to the dynamic development of the company, should be the lifelong learning in the area of social problems relating to a threat to the position of the individual in the narrowest social group (Fischer, \& Škoda, 2014; Vágnerová, 2014, p. 317). Appropriate content and form of the prevention of the lecture, seminar, discussion, etc. in the places where they meet senior citizens, would certainly contribute to greater awareness and prevention for this generation the role of the victim.

\section{THE CONCLUSION}

Why the violence in families does occure? What is the awareness of the respondents about a high-risk behavior, called the domestic violence? Not only this questions asking for, we are trying to describe a reconnaissance answer, by the respondents - the elderly. The benefit probe, is the finding that in the area of primary preventiv, there is a space, which could undoubtedly, after the filling contribute to a greater possibility of the defense against the examinee violence.

The family should be for its members, especially in today's era, the place of the peace, safety, understanding and love. Often it is, however, rude, dismissive, hostile environment. The senior is lik as a child, like a direct or an indirect victim. The age of the elderly it brings with him a vulnerability, physical illness, psychological disease, often it brings economic dependence on their offspring, to the naive gullibility and faith in change in the situation for the changeing to be the better. The latency of the domestic violence in the elderly, it is primarily the existence of fact of the shame and the fear that the public will reveal the violent - the immoral behavior of his tormentor - a member of the family. The existing problem is confirmed by the questions, the seniors asked after the end of the lectures. The most common questions were related to the economic relationships between parents and children. Often the donation of an apartment or house from the parents - the elderly person to his descendant, is the impetus for the violence. If people are interested in socio-pathological problems, they have questions and they do not turn to the problem of back, it's the best way to address the risks in behavior and mitigate any consequences.

\section{REFERENCES}

[1] Bílý Kruh Bezpečí. (2016). Pomoc obětem trestných činů v ČR [Assistance to crime victims in the Czech Republic]. Retrieved from http://www.bkb.cz/.

[2] Buskotte, A., \& Vaníčková Horníková, L. (2008). Z pekla ven: žena v domácím násilí [Out of Hell: A woman in a domestic violence]. Brno: Computer Press.

[3] Čírtková, L. (2014). Viktimologie pro forenzní praxi [Victimology in the forensic practice]. Praha: Portál. 
[4] Buriánek, J. (Ed.). (2006). Domácí násilí - násilí na mužích a seniorech [Domestic violence - violence against women and seniors]. Praha: Triton.

[5] Fischer, S., \& Škoda, J. (2014). Sociální patologie: závažné sociálně patologické jervy, př̌činy, prevence, možnosti řešení [Social Pathology: serious social pathologies, causes, prevention, possible solutions]. Praha: Grada.

[6] Machalová, T. (2014). Domácí násili: filosofická analýza pojmu [Domestic violence: a philosophical analysis of the concept]. Brno: Masarykova univerzita.

[7] Ševčík, D., \& Špatenková, N. (2011). Domácí násilí: kontext, dynamika a intervence [Domestic violence: the context, dynamics and intervention]. Praha: Portál.

[8] Šmejkalová, K. (2011). Problematika domácího násilí a jeho prevence [The issue of domestic of violence and prevention]. (Diplomová práce). Vedoucí diplomové práce prof. JUDr. Ing. Viktor Porada, DrSc., Bratislava: PEVŠ.

[9] Vágnerová, M. (2014). Současná psychopatologie pro pomáhající profese [Current psychopathology for the helping professions]. Praha: Portál.

[10] Voňková, J., \& Spoustová, I. (2008). Domácí násilí v českém právu z pohledu žen [Domestic violence in Czech law from the perspective of women]. Praha: proFem.

[11] Masarykova univerzita, Univerzita třetího věku. Retrieved January 23, 2016, from http://u3v. muni.cz/o-nas/.

[12] Národni akční plán prevence domácího násili na léta 2010-2014. Domácí násilí Mlegislativa/ ko [National Action Plan for the Prevention of Domestic Violence for the Years 2010-2014. Domestic Violence /legislation/ ko.]. Retrieved January 25, 2016, from http://www.koordona.cz/domaci-nasili/legislativa/60-narodni-akcni-plan-prevence-domaciho-nasili-naleta-2010-2014.html.

[13] Úmluva Rady Evropy o prevenci a potírání násilí vi̊či ženám a domácího násilí. Istambul 11.V.1911 [Council of Europe Convention on preventing and combating violence against women and domestic violence. Istambul 11.V.1911]. Retrieved January 23, 2016, from http://xoe.int/t/ $\mathrm{dghl} /$ standardsetting/convention-violence/convention/Convention $\% 20210 \% 20$ Czech.pdf.

[14] Úřad vlády ČR. (2015). Akční plán prevence domácího a genderově podminěného násilí na léta 2015 - 2018 [Action Plan for the prevention of domestic and gender-based violence for the years 2015 - 2018]. Retrieved from http://www.dejmezenamsanci.cz/res/data/010/004403.

[15] pdf?seek $=4$.

\section{Appendix 1}

\begin{tabular}{|c|c|c|c|}
\hline $\begin{array}{l}\square \quad \text { man } \\
\square \quad \text { woman }\end{array}$ & THE QUES & IONNAIRE & \\
\hline \multicolumn{4}{|c|}{ Do you think the issue of domestic violence is really a social problem? } \\
\hline$\square$ yes & $\square$ rather yes & $\square$ rather not & $\square$ no \\
\hline \multicolumn{4}{|c|}{ Does the legislation protect the victims of domestic violence sufficiently? } \\
\hline$\square$ yes & $\square$ rather yes & $\square$ rather not & $\square$ no \\
\hline \multicolumn{4}{|c|}{$\begin{array}{l}\text { Do you think the current law acts prevent against the occurrence of a domestic } \\
\text { violence? }\end{array}$} \\
\hline$\square$ yes & $\square$ rather yes & $\square$ rather not & $\square \quad$ I can't assess \\
\hline \multicolumn{4}{|c|}{$\begin{array}{l}\text { According to your opinion, who are the victims most frequently through the } \\
\text { social profile of the domestic violence? }\end{array}$} \\
\hline $\begin{array}{l}\square \quad \text { children } 0-10 \\
\text { years }\end{array}$ & $\begin{array}{l}\square \quad \text { children } 11-18 \\
\text { years }\end{array}$ & $\begin{array}{l}\text { working } \\
\text { women in a } \\
\text { productive age }\end{array}$ & $\begin{array}{l}\square \text { working men } \\
\text { in a productive } \\
\text { age }\end{array}$ \\
\hline
\end{tabular}




\begin{tabular}{|c|c|c|c|}
\hline Seniors & \multirow{2}{*}{\multicolumn{3}{|c|}{ experience with the communication with the police in the }} \\
\hline $\begin{array}{l}\text { Do you have a good experience with the communication with the police in the } \\
\text { Czech Republic? }\end{array}$ & & & \\
\hline$\square$ yes & $\square$ rather yes & $\square$ rather not & $\square$ no \\
\hline \multicolumn{4}{|c|}{ Do you think we can prevent the domestic violence? } \\
\hline$\square$ yes & $\square$ rather yes & $\square$ rather not & $\square$ no \\
\hline \multicolumn{4}{|c|}{$\begin{array}{l}\text { What in your opinion is the most serious problem in the detection of the } \\
\text { domestic violence? }\end{array}$} \\
\hline \multicolumn{4}{|c|}{ Do you know, what a subject would you contact being a offer? } \\
\hline$\square$ yes & $\square$ rather yes & $\square$ rather not & $\square$ no \\
\hline \multicolumn{4}{|c|}{ 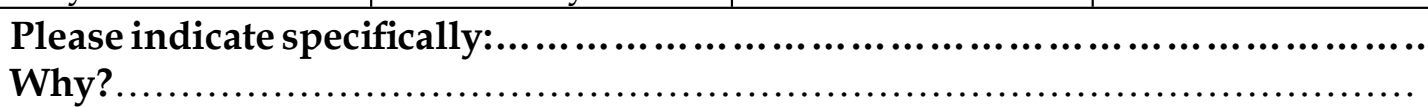 } \\
\hline \multicolumn{4}{|c|}{$\begin{array}{l}\text { Have you ever participated in the lectures on the topic of the domestic violence } \\
\text { in the past? }\end{array}$} \\
\hline$\square$ yes & $\square$ rather yes & $\square$ rather not & $\square$ no \\
\hline
\end{tabular}

Date: 